\title{
SOCIAL MEDIA THEORIES \\ IN CRITICAL DISCOURSE ANALYSIS (CDA)
}

\author{
Zonianus Mendrofa \\ Department of English Faculty of Teacher Training and Education \\ Universitas Lancang Kuning, Pekanbaru, Riau, Indonesia \\ jhonymendrofa@gmail.com
}

\begin{abstract}
Social Media can be conceptualized as an emerging frontier where new forms of social relations expand at the junction of human collective communicative and technology of information. Discussion about CDA place in critical information systems (IS) research, with an example of a CDA study applied to social media this discussion service to inform $I S$ researchers of a decent option for theory building in social media.
\end{abstract}

Keywords: Critical discourse analysis, critical information system, social media, theories building

\section{INTRODUCTION}

This paper discussion Critical Discourse Analysis (CDA) as approach for theory improvement in social media. This chapter they discussion around CDA in important information system research and the example of a CDA study applied in social media and discussion is used to inform IS (information system) to build theory in social media. the researcher's ability to address issues related to social and influenced by IS (information System) related to the attractiveness and usefulness of critical research and specifically in the case of CDA where power imparity between social actors and language and communication can be used for coercion, control, discrimination and victimization. Social media can be conceptualized as an emerging frontier where new forms of social relations develop at the intersection of human collective communicative acts and information technology.

Social media can be conceptualized as and developing borderline where new forms of social relations develop at the connection of human collective communicative actions and information technology. This created a need for allowing for novel approaches for research in social media. It is our contention that CDA provides such an approach. The critical vantage point suggestions a 
complimentary machine for evaluation of social media related phenomena as it "comprises individual, organizational, and social issues. Though, a challenge for IS researchers pointing to study these phenomena relates to the need for developing social media theories.

Critical Discourse Analysis (CDA) approach has been used to study social phenomena in such sector as education and organizational studies in combination with domain theories, CDA is a means for both theory improvement and theory expansion. An example of the principles for direction of critical research as applied to a CDA study is provided.

\section{BACKGROUND: STRANDS OF CRITICAL DISCOURSE ANALYSIS}

Basically, a CDA approach is established to examine "opaque as well as translucent structural relationships of dominance, discrimination, power and control as established in language" (Wodak and Meyer, 2008 p. 10). This approve to IS researchers the selection to consider theories from sister disciplines like sociology, psychology, management, economics, anthropology, etc., to develop our understanding of these complex social practices in which social media is playing ever-increasing critical role. Although not tight to a single methodology or theory, there are suggested types of approaches that decrease in the umbrella of CDA. A synopsis of theoretical position, methodological objects, and data types of these six approaches is provided in Table 1 as abridged from Wodak and Meyer (2008).

This immediate tells the flexibility of CDA. Efforts of the approaches variety from social actor to discourse structure. The socio-cognitive and social actors' approach give focus to the notion of an individual having agency inside social situations. Such individual actions affect social structures and interactions create perceptions of social groups. On the other hand, the historical-discourse and dialectical-relational approach focuses on the grammar of the language situation and social situation which it is established. The dispositive approach grips for the respect of the realism of humanity if stated in discourse, excluding non-linguistic elements from social action Focus on linguistic tools, the stages of a corpus 
linguistic approach can be endorsed along with five other approaches (Wodak and Meyer, 2008). Understanding focus of dissimilar approaches is wanted to control which is applicable for learning a sensation. For example, if anyone using text messages the initial adolescent behavior of choice from Table 1 may be a dialectical -relational approach. This will be possible speakers for the reciprocal translation between socializing and language built round such socialization.

Same as theoretical situations and methodological objects are observed in the CDA approach, so the technique of operation. Techniques school/macro to detailed / micro linguistic. Because of its operations through software, the corpuslinguistic approach is based on a very important approach to large data sets. The dispositional analysis, the socio cognitive approach, the social actors approach and the dialectical relational approach can all be made to the existing text. It is recommended that field work and / or ethnographic research classify as a historical approximation. The idea of using existing data, whether large or small, corresponds to social media research, because there is a large amount of data in social media.

In fact, credited the linguistic approach of the corpus, challenging critical discourse analysis of researchers to utilize the web for moral judgment. He reveals that, because the physical situation is so dynamic and flexible, it reacts at an unprecedented pace and expects social change, because they are highly accessible than print media it is inherently more democratic. Understand the method of operation and data type of each appropriate approach when choosing the right phenomenon to know the phenomenon of research. For example, if someone can recognize the selected parent from table 1. This will enable further research to understand the subject of a large company message text to revise the impact of interconnectedness based on the relationship and the language constructed about the socialization. 
Table 1. Approaches of Critical Discourse Analysis (Wodak \& Meyer, 2008)

Corpus Linguistics Approach (Gerlinde Mautner)

Theoretical position: linguistic extension of CDA

Methodological objectives: improved analysis through additional linguistic devices

Data: Large corpora of text

Discourse-Historical Approach (Ruth Wodak and Martin Reisigl)

Theoretical position: connections between fields of action, genres, discourses and texts

Methodological objectives: development of "conceptual tools relevant for specific social problems

Data: Existing text, fieldwork, ethnography

Social Actors Approach (Theo van Leuuwen)

Theoretical position: individual actors constitute and reproduce social structure

Methodological objectives: detailed linguistic operationalization at the actor level

Data: Existing Text

Dialectical-Relational Approach (Norman Fairclough)

Theoretical position: language is "shaped by the social functions it has come to serve" (p. 27)

Methodological objectives: analyze dialectical relationships between functions of signs and other elements of social practices

Data: Existing text

Dispositive Analysis (Siegfried Jäger \& Florentine Maier)

Theoretical position: the link between discourse and reality is the social acting subject

Methodological objectives: discourse and dispositive analysis

Data: Existing text

Socio cognitive Approach (Teun van Dijk)

Theoretical position: the link between social systems and individual cognitive systems are socially shared perceptions

Methodological objectives: development of context models/social representations of the communicative situation

Data: Existing text

Some steps complicated in the six CDA approaches relate to the inherent aspects of social media. Simple ideas from Discourse provide close intercultural relationships and medium communications. Social mediations are derived from the local, global, and global-level, initiator, and measurement factors that they encounter not in a CDA approach. To better understand the relationship between CDA social media, system management media's role as a lengthy system. 


\section{SOCIAL MEDIA AND CRITICAL DISCOUSE ANALYSIS AS A DISCURSIVE SYSTEM}

From definition, the discursive system consists of a double view, also recognized as the universe of nature. The universe discourses this aside in the act of social media communications. In This dialogical interchange enables discourselike acts such as building relationships, developing social situations and intellectual forces that can potentially influence or interfere with social issues. Social movements, intimidation and online sexual exploitation of children online are examples of social issues that are influenced or initiated by discourse within and / or social media structures.

The purpose of most social movements is the authorization of young people. Motivation toward empowerment with CDA in both functions to increase the reality of lower society groups. In contrast, virtual bullying and online sexual predation are situations where vulnerable populations become victims through discourse in social media. In this case, the CDA can be experienced in understanding the imbalance of forces between the offender and the victim to improve the vulnerable social environment of the susceptible populations.

Social movement is "a form cooperative act that articulates a social conflict and ultimately aims to change the social order: it is the process of interaction and interaction when confronting the underlying development of the enforcement of the identity of the perspective. This definition draws the notion of discourse through the concepts of action and interaction. The idea of a transformation of the social order can reconnect awareness of the CDA, improve the lives of ordinary people. One of the most identifiable social movements in this new history is the Egyptian revolution. This is a good example of building relationships, the development of social situations and the intellectual strength that is done through the broad system of social media.

Cyber bullying is another example of a social problem in which IS research is entangled. Defined as Intentional and The recurring losses incurred through the use of cell phones and electronic devices, cyber bullying has emerged as a harmful undesirable consequence of social media Social media aggravates the 
danger of "giving anonymity and an opportunity to reach a much larger number of victims without a significant penalty threat The most recent cyber-cruel case of cruelty is known to occur Place on the Rutger's University campus where Dharun Ravi filmed his roommate, Tyler Clementi, engaged romantically, meet other men and stream online.

Finally, online sexual predictions of children present other social issues in the study of related research. The study of online predatory treatment methods has examined their psychosocial traits against exploited children. By clinically exposed children may detect several simultaneous occurrences, hide behind a disguise of secrecy and general information about the birth of children. Through predators' online predators can sacrifice children with images, live webcams and hyperlinks. Relationships in this discourse exist between children and adolescents. The formulation of socialization is a pastor by online predators to move children / women dressed. The imbalance of strength can account for the children's vaccination.

Every example of the social problem presented here presents a unique discourse universe from which IS cannot be separated. Discourse in social media impact on society and life of layman. With a focus on the discourse and practice of the power and sociocultural discourse, the Critical Discourse Analysis approach would be a good choice for researching phenomena and turning to theory in social media. As a type of communication technology and information social media symbolizes the ability for the user through its functional properties that determine its use.

This includes the idea of risk lies in the consequences of unwanted use of social media. About information technology, history provides an example of unintended technological consequences, a time when "technology is not necessarily has been taken or used as before. In the next section we present an overview of ongoing research using CDA in the evaluation of the consequences of unsolicited social media, online sexual predation of children. 


\section{PREDATORY COERCION IN SOCIAL MEDIA: ILLUSTRATION OF THE CDA APPROACH IN THEORY BUILDING}

The quantity for this study is a subset of the Worst Trial transcripts that include "23,237 chat lines consisting of 112 keywords, as many as 455 words. The models of theory include coercion, alternative social realism, reactance, learning disabilities and social control. In this example, coercion is the use of power, control of activity and change by predators for the control of social situation discourse. The different social reality is the textual context in which predators inspire the image of it that he wants, but it really suits the desire of the predator.

Reactance is a child's engagement in behaviors / activities that the authority seeks to limit. The helplessness learned is a child's resignation to a reality that will not change his actions. Social control is the involvement of the child in the behavior / activity that he / she feels will bring happiness, justice and / or satisfaction. Using this construction, a proposed theoretical model was established and then estimated using a dialectical interactive approach.

The dialectical-relational approach (DRA) requires three stages; the first is discourse. This is an evaluation of the text between predators and children for choices and patterns in vocabulary, grammar, cohesion, and text structure. From this step, the example of the proposed theoretical model reveals variations of coercive application through communicative discourse in social media. In the second stage of the DRA, discourse as practice, the text is evaluated for speech acts, coherence, intertextuality and recognized processes (Cukier et. From this step, the result from the relationship among the author and the discourse reader, the structural effects of discourse and the attributes of social media on the discourse are revealed. In the final stages of DRA, sociocultural practices, the idea of online sexual predators spreading their ideology in social media, as well as the acceptance of the ideology have been addressed.

Through online sexual forecast these children are recognized as a social issue. Social media is recognized as a discursive system with institutional attributes that affect discourse. 
Table 2. Execution of CDA through a Principles of Critical Research Lens Adapted from (Myers \& Klein, 2011)

\begin{tabular}{|c|c|c|}
\hline $\begin{array}{l}\text { Element of } \\
\text { Critique }\end{array}$ & $\begin{array}{l}\text { Dialectical-Relational } \\
\text { Approach }\end{array}$ & $\begin{array}{l}\text { Predatory Coercion in Social } \\
\text { Media Example }\end{array}$ \\
\hline $\begin{array}{l}\text { 1. Principle of } \\
\text { using core } \\
\text { concepts from } \\
\text { critical social } \\
\text { theorists }\end{array}$ & $\begin{array}{l}\text { Allows for use of } \\
\text { constructs from pertinent } \\
\text { domain theories }\end{array}$ & $\begin{array}{l}\text { Utilizes constructs of coercion, } \\
\text { alternate social realities, } \\
\text { reactance, learned helplessness } \\
\text { and social control }\end{array}$ \\
\hline $\begin{array}{l}\text { 2. Principle of } \\
\text { taking a value } \\
\text { position }\end{array}$ & $\begin{array}{l}\text { Rooted in discourse, } \\
\text { promotes the use of a } \\
\text { discursive lens }\end{array}$ & $\begin{array}{l}\text { Employs lens of social media as a } \\
\text { discursive system }\end{array}$ \\
\hline $\begin{array}{l}\text { 3. Principle of } \\
\text { revealing and } \\
\text { challenging } \\
\text { prevailing } \\
\text { beliefs and } \\
\text { social practices }\end{array}$ & $\begin{array}{l}\text { Includes evaluation of } \\
\text { ideology and hegemony, } \\
\text { potentially challenging } \\
\text { what is 'known' or } \\
\text { accepted }\end{array}$ & $\begin{array}{l}\text { Challenges the idea of online sex } \\
\text { offenders having weak ideological } \\
\text { power }\end{array}$ \\
\hline $\begin{array}{l}\text { 4. Principle of } \\
\text { individual } \\
\text { Emancipation }\end{array}$ & $\begin{array}{l}\text { Provides mechanism for } \\
\text { revealing } \\
\text { human needs, potential } \\
\text { and self-reflection } \\
\text { through discourse }\end{array}$ & $\begin{array}{l}\text { Shows how sexual predators are } \\
\text { able to fulfill their ideological } \\
\text { desires through social media }\end{array}$ \\
\hline $\begin{array}{l}\text { 5.Principleof } \\
\text { improvements in } \\
\text { Society }\end{array}$ & $\begin{array}{l}\text { Includes step for } \\
\text { evaluating and } \\
\text { recommend improvements } \\
\text { to society and culture } \\
\text { impacted by context of } \\
\text { study }\end{array}$ & $\begin{array}{l}\text { Recommends further research of } \\
\text { Online sexual predator } \\
\text { communicative acts toward } \\
\text { improved protection for children } \\
\text { online }\end{array}$ \\
\hline $\begin{array}{l}\text { 6. Principle of } \\
\text { improvements in } \\
\text { social theories }\end{array}$ & $\begin{array}{l}\text { Allows for theoretical } \\
\text { enhancements through use } \\
\text { of domain theories and } \\
\text { recommendations for } \\
\text { societal } \\
\text { improvements }\end{array}$ & $\begin{array}{l}\text { Proposes theoretical model for } \\
\text { study of predatory coercion inside } \\
\text { social media }\end{array}$ \\
\hline
\end{tabular}

Like previous, there are also optional principles for using a critical radical (CR) exemplar with case studies in IS research. Table 3 contains a comparison of the principles of a critical realist approach put forth by Wynn and Williams (2012) with the dialectical relational CDA approach. Similarities exist between critical realism and dialectical relational CDA. In addition, both use the idea of the power 
and the idea that social structures and physicists can not identify the contextual environment and thus the event.

There is a difference between CDA and CR that is important for social media theory. The discriminating aspect of the CDA is the first step of the analysis of the language.In fl ere is considered to use the rules to understand the structures and theitekseks to identify the theoretical construct manifestations in the discourse. This is important for the development of social media theory because in social media, the text is a driving event. A theme that is held firmly to change the future then the first republic thereof because of the mechanism imposed by predators for children toward victimization. Understanding how the text is made in the predecessorship and the way in which to secure power for predators.

Table 3. Comparison of Critical Realist Principles and Dialectical-Relational CDA Approach (Wynn \& Williams, 2012)

\begin{tabular}{|c|c|c|}
\hline CR PRINCIPLE & DEFINITION & $\begin{array}{c}\text { DIALECTICAL- } \\
\text { RELATIONAL CDA }\end{array}$ \\
\hline Explication of Events & $\begin{array}{l}\text { Foundation for } \\
\text { phenomenological } \\
\text { understanding based on } \\
\text { identification and abstraction of } \\
\text { event. }\end{array}$ & $\begin{array}{l}\text { Discourse : events and } \\
\text { text }\end{array}$ \\
\hline $\begin{array}{l}\text { Explication of Structure } \\
\text { and Context }\end{array}$ & $\begin{array}{l}\text { Social and physical } \\
\text { structure,contextual } \\
\text { environment,relationships } \\
\text { among these }\end{array}$ & $\begin{array}{l}\text { Discourse: structure and } \\
\text { contextual environment } \\
\text { Discourse as Practice: } \\
\text { relationships between } \\
\text { structure } \\
\text { environment }\end{array}$ \\
\hline Retroduction & $\begin{array}{l}\text { Powers, impact of structure on } \\
\text { events }\end{array}$ & $\begin{array}{l}\text { Discourse as Practice: } \\
\text { how text is produced } \\
\text { and transformed impacts } \\
\text { the event, role of } \\
\text { institution in the even }\end{array}$ \\
\hline Empirical Corroboration & $\begin{array}{l}\text { Causal power, best explanatory } \\
\text { power }\end{array}$ & $\begin{array}{l}\text { Discourse as Practice: } \\
\text { evidential validation of } \\
\text { theoretical relationships } \\
\text { Sociocultural Practice: } \\
\text { evidential revelation of } \\
\text { connections between } \\
\text { social structure, social } \\
\text { practices and discourse } \\
\text { practices }\end{array}$ \\
\hline
\end{tabular}




\begin{tabular}{|l|l|l|}
\hline $\begin{array}{l}\text { Triangulation\&Multimeth } \\
\text { ods }\end{array}$ & $\begin{array}{l}\text { Multiple approaches used to } \\
\text { support causal analysis }\end{array}$ & $\begin{array}{l}\text { Does not restrict } \\
\text { methodology or theory } \\
\text { employed by researcher }\end{array}$ \\
\hline
\end{tabular}

There is an in-depth, wide-ranging question inherent in the development of social media theory because of accessible digital data. Its application of CDA theoretical offered as one optionto address thisproblem(Urquhart and Vaast2012). This paper is supported by recommendations.

\section{CONCLUSION AND IMPLICATIONS FOR FUTURE RESEARCH}

The Critical Discourse Analysis offers a theoretical approach to the problem of social problems through discourse analysis. Social media is a discursive system in which social issues are enacted through textual discourse. Together, these elements provide IS researchers with many phenomena. Previously, social movements, cyber intimidation and online sexual predation were three phenomena in social media that could be examined. However, those issues are indeed the tip of the iceberg. Critical Discourse Analysis offers a theoretical aspect to overcome the social media theory deficit in IS. This paper presents six CDA approaches, which describe its use as a scientific work. Social media is a discursive system that is a social issue.

After that, the dialectical-relational $\mathrm{CDN}$ approach with the research principles at IS, results in alignment. An example of the dialectical relational approach adopted in the mediasocial to see the predictors of supported children as evidence. The results of this comparison show the similarity between the two, although the CDA records them differently in linguistic techniques. The next step in terms of child sexual prediction using CDA will include developed theoretical testing, applying grounded theory to data via CDA for exploratory purposes to ensure all appropriate constructs are exposed in theoretical and intermediate contexts if this step is built on this model. This approach provides access that I think, in the developed world, is very important to the economy and society. 


\section{REFERENCES}

Hamuddin, Budianto. A comparative study of politeness strategies in economic journal. Diss. University of Malaya, 2012.

Chouliaraki, L., \& Fairclough, N. L. (1999). The critical analysis of discourse. Discourse in Late Modernity (pp. 60-69)

Albert, C. S., \& Salam, A. F. (2012). Predatory Coercion in Social Media and Protection of Children Online - A Critical Discourse Analysis Approach. International Conference on Information Systems (pp. 1-10).

Hamuddin, Budianto, “Discourse on Media: Bringing Hot News into ELT's Classroom Discussion." Proceedings of ISELT FBS Universitas Negeri Padang 3 (2015): 87-95.

Hinduja, S., \& Patchin, J. W. (2011). Bullying, Cyberbullying, and Sexual Orientation. 